\title{
Evaluation of Wheat Cultivars for Growth and Yield Traits under Agro-Ecological Condition of Tandojam
}

\author{
Tofique Ahmed Bhutto ${ }^{1}$, Mahmooda Buriro ${ }^{1}$, Niaz Ahmed Wahocho² ${ }^{2}$ Safdar Ali Wahocho' ${ }^{2}$, Muhammad \\ Iqbal Jakhro ${ }^{3 *}$, Zulfiqar Ali Abbasi ${ }^{1}$, Reema Vistro ${ }^{1}$, Fehmeeda Abbasi ${ }^{1}$, Sanam Kumbhar ${ }^{1}$, Fateh \\ Muhammad Shawani ${ }^{4}$ and Nadar Hussain Khokhar ${ }^{5}$
}

${ }^{1}$ Department of Agronomy, Sindh Agriculture University, Tandojam-70060, Pakistan; ${ }^{2}$ Department of Horticulture, Sindh Agriculture University, Tandojam-70060, Pakistan; ${ }^{3}$ PARC, Agricultural Centre, Quetta, Balochistan, Pakistan; ${ }^{4}$ Department of Plant Breeding and Genetics, Lasbela University of Agriculture, Water and Marine Sciences, Uthal-90150, Pakistan; ${ }^{5}$ Civil Engineering Department, Balochistan University of Engineering and Technology, Khuzdar-89100, Pakistan.

\begin{abstract}
Cultivation of low genetic potential cultivars is one of the main factors which cause yield reduction in wheat. In this regard, the selection of new high yielding cultivars with better adaptability to local conditions is important for growth and yield associated traits. The highly varied performance of crop cultivars of the same species for growth and yield-related attributes is well documented. The present investigation investigated the performance of wheat cultivars under Tando Jam conditions. For this study, two-year field experiments were performed during October 2015-2017 (both seasons) applying randomized complete design with three replications. Performance of various wheat varieties for their yield and yield-related characters, including TD-1, Moomal-2002, Anmol-91, and Imdad-2005 were investigated. The results demonstrated that all the cultivars showed significantly varied performance for growth and yield-related traits. However, TD-1 and Moomal-2002 comparatively showed better performance for most of the investigated parameters. Cultivar Moomal-2002 performed better for vegetative traits viz; seed emergence $\left(\mathrm{m}^{-2}\right)$, tillers plant ${ }^{-1}$, plant height $(\mathrm{cm})$ and biological yield $\left(\mathrm{kg} \mathrm{ha}{ }^{-1}\right)$. However, TD-1 proved to superiority in yield-related contributes such as spike length $(\mathrm{cm})$, spikelets spike ${ }^{-1}$, grains spike ${ }^{-1}, 1000$ grain weight $(\mathrm{g})$, and grain yield $\left(\mathrm{kg} \mathrm{ha}^{-1}\right)$ under both seasons. Among all cultivars, Imdad-2005 revealed the lowest values for all the scored traits. Based on the finding of the current study, it is concluded that the wheat cultivars TD-1 and Moomal-2002 performed better in terms of growth, yield, and yield characters as compared to the rest of the cultivars in both years. Therefore, wheat cultivars TD-1 and Moomal-2002 may be grown under the agro-ecological conditions of Tandojam, Sindh, Pakistan.
\end{abstract}

Received | October 04, 2020; Accepted | December 23, 2020; Published | March 03, 2021

*Correspondence | Muhammad Iqbal Jakhro, PARC, Agricultural Centre, Quetta, Balochistan, Pakistan; Email: iqbal.jakhro@gmail.com Citation | Bhutto, T.A., M. Buriro, N.A. Wahocho, S.A. Wahocho, M.I. Jakhro, Z.A. Abbasi, R. Vistro, F. Abbasi, S. Kumbhar, F.M. Shawani and N.H. Khokhar. 2021. Evaluation of wheat cultivars for growth and yield traits under agro-ecological condition of Tandojam. Pakistan Journal of Agricultural Research, 34(1): 136-143.

DOI | http://dx.doi.org/10.17582/journal.pjar/2021/34.1.136.143

Keywords | Wheat, Cultivars, Adaptability, Yield and Tandojam, Sindh, Pakistan

\section{Introduction}

W heat is one of the world's necessary food cereal crops as well growing in large areas. It is an important cereal food crop that provides many essential nutrients to humans and animals. Wheat is well known as stable food and meet the food requirement of the human population globally; it can 
be easily processed, stored, transported, and refined as well as consumed as raw food (Elias, 2003). Wheat crop is a widely grown and produced more grains cereal crops of Pakistan. It is highly consumed and meets the increasing food demand of the country. In Pakistan wheat contributes 9.1 and $7.1 \%$ to the value-added in agriculture and contributes $3.0 \%$ to GDP. It is reported that the total area under wheat cultivation in $2017-18$ was 8.734 million ha $^{-1}$ with a production of 25.492 million tons (GOP, 2017-18). Available shreds of evidence have revealed that yield per unit area of the wheat cultivars grown in Pakistan is beyond their potential exists (Iqbal et al., 2001). The improper sowing time, poor cultural practices, nonjudicious use of fertilizers, and improper irrigation are one of the main constraints of the low yield of wheat in Pakistan (Tahir et al., 2009). Besides this, the growth of cultivars with low productivity is one of the causes of the low yield of wheat in Pakistan. The losses of yield may be decreased markedly through the cultivation of more yielding genotypes with better insect and disease resistance potential (GOP, 2013). The highly varied response of wheat cultivars to fertilizers and environmental conditions is well documented (Naeem, 2001; Ali et al., 2010). Haider (2007) observed that the growth and yield potential of wheat variety was significantly influenced by environmental conditions. The crop grown in a specific area needs optimum growth conditions for satisfactory growth, yield, and development. It has been well established that every cultivar of wheat required species growth conditions including, temperature, humidity for vegetative and reproductive growth, and development (Aslani and Mehrvar, 2012). Growing period of wheat crop plays a significant role in enhancing the growth and yield, hence sowing of any crop at a proper time needs to be investigated critically. Several lines of shreds of evidence have revealed the pivotal role of sowing time in increasing the productivity of wheat. Kumar et al. (2003) found that the sowing period $20^{\text {th }}$ November was produced better yield as compared to $1^{\text {st }}$ November or $10^{\text {th }}$ December of wheat crop. Ali et al. (2014) reported a $27-52 \%$ reduction in grain yield on sowing dates (15 and 31 December), respectively. (Tahir et al., 2009) recorded a better yield of wheat when sowing of the crop was done from $15^{\text {th }}-30^{\text {th }}$ November under the environmental conditions of Bahawalpur. Shah and Akmal (2002) performed a trial on four cultivars of wheat. The sowing was carried out from $24^{\text {th }}$ October to $11^{\text {th }}$ December at an interval of 15 days. There was a $28 \%$ decrease in yield due to the late sowing of wheat crop. The diverse climatic conditions of Pakistan provide ample opportunities for a growing wide cultivar of crops. However, these climatic conditions vary in different agro-ecological zones. Hence, the adaptability of wheat cultivars under local agro-ecological conditions is a prerequisite for the sustainability of yield and yield-related characters. In light of the above-mentioned facts, the present investigation was investigated to performance of the wheat cultivars for growth and yield-related traits under the agro-ecological condition of Tandojam.

\section{Materials and Methods}

\section{Experimental site}

The present experiment was laid out at Agronomy Section, A.R.I, Tandojam using randomized complete block design with three replications having a net plot size of $15.75 \mathrm{~m}^{-2}$. The four wheat cultivars namely viz; TD-1, Moomal-2002, Anmol-91 and Imdad-2005 were evaluated for their growth and yield-related characters under local conditions of Tandojam for two successive years 2015-16 and 2016-17.

\section{Soil preparation}

The soil was prepared by recommended various ploughs for better distribution of irrigation and fertilizers as well as better germination, growth, and development of the crop. The primary implements viz; disc plough and subsoiler were used to remove the compaction of the soil. After that big clods were crushed, and soil was levelled properly. After soaking dose, secondary tillage implements viz; disc harrow and cultivator were used for seedbed preparation.

\section{Sowing of the crop}

The seeds were sown through a local hand drill with recommended rate $100 \mathrm{~kg} \mathrm{ha}^{-1}$ on prepared each treatment plot. In this method the seeds were dropped at the proper depth and resulted uniform germination and better growth stand.

\section{Cultural practices}

The recommended dose of NP @120-60 kg ha ${ }^{-1}$ was applied uniformly in the whole study area. The whole dose of phosphorous plus $1 / 2$ rate of the nitrogen was applied at sowing time and the remaining $1 / 2$ of the nitrogen was applied on $1^{\text {st }}$ and $3^{\text {rd }}$ irrigations, respectively. The weedicide namely (Logran ${ }^{\circledR} 750 \mathrm{~g}$ $\mathrm{Kg}^{-1}$ Triasulfuron) was applied for the control of weeds after $1^{\text {st }}$ and $2^{\text {nd }}$ irrigations. All other cultural practices 
including hoeing and irrigation were performed uniformly in all experimental plots throughout the growing season. The all agronomic traits viz; seed emergence $\left(\mathrm{m}^{-2}\right)$, tillers plant $\mathrm{t}^{-1}$, plant height $(\mathrm{cm})$, spike length $(\mathrm{cm})$, spikelets spike ${ }^{-1}$, grains spike ${ }^{-1}, 1000$ grain weight $(\mathrm{g})$, grain yield $\left(\mathrm{kg} \mathrm{ha}^{-1}\right)$, and biological yield $\left(\mathrm{kg} \mathrm{ha}^{-1}\right)$ were noted from sowing to harvest.

\section{Methodology for recording phenotypic traits}

Seed emergence $\mathbf{~ m}^{-2}$ : The data concerning seed emergences was obtained from each plot for the counting number of emergences. The seed emergences were counted ten days after sowing in the square meter at the cropped area.

Tillers plant ${ }^{-1}$ : Tillers plant $^{-1}$ were recorded from three locations of each treatment at 50\% physiological maturity of wheat crop.

Plant height (cm): The plant height of selected plants was measured through measuring tape in centimetres.

Spike length (cm): The spike length was measured from base point to tip of a spike by measuring tape in centimetres.

Spikelets spike ${ }^{-1}$ : The five plants were randomly selected from each cultivated cultivar for the counting of spikelets spike ${ }^{-1}$ at the harvest time. The number of spikelets was scored from each spike individually.

Grains spike ${ }^{-1}$ : After threshing, the number of grains spike $^{-1}$ was scored from randomly tagged spikes of each treatment.

1000-grain weight (g): The 1000 grain weight (g) was recorded from each cultivated plot for the counting of 1000 seeds and their balance was taken through digital balance.

Biological yield ( $\left.\mathbf{k g ~ h a}^{-1}\right)$ : The biological yield was calculated by weighing the whole foliage and grains obtained from each plot.

$$
\text { Biol yield per hectare }(\mathrm{kg})=\frac{\text { Yield per plot }(\mathrm{kg})}{\text { Per plot area }(\mathrm{m} 2)} \times 10000
$$

Grain yield ( $\left.\mathrm{kg} \mathrm{ha}^{-1}\right)$ : The grain yield was recorded by using the following formula.

$$
\text { Grain yield per hectare }(\mathrm{kg})=\frac{\text { Yield per plot }(\mathrm{kg})}{\text { Per plot area }(\mathrm{m} 2)} \times 10000
$$

Data analysis

The data were obtained and statistically analyzed through Statistix 8.1. The resulted means were recorded individually using the least significant difference (LSD) test at the $5 \%$ level of probability.

\section{Soil condition}

The Physico-chemical properties of the experimental soil such as soil texture, soil $\mathrm{pH}$, soil EC, organic, total nitrogen, available phosphorus, available potassium is presented in (Table 1).

Table 1: Soil properties of experimental field which used

\begin{tabular}{|c|c|c|c|c|}
\hline \multirow{2}{*}{\multicolumn{3}{|c|}{ Soil properties }} & Season-I & Season-II \\
\hline & & & Value & Value \\
\hline \multirow{10}{*}{$\begin{array}{l}\text { Soil } \\
\text { depth } 14 \text {, } \\
30,45, \\
60 \mathrm{~cm}\end{array}$} & \multirow{3}{*}{ Texture } & Sand (\%) & 27.5 & 27.5 \\
\hline & & Silt (\%) & 41.5 & 41.5 \\
\hline & & Clay (\%) & 29.2 & 29.2 \\
\hline & \multicolumn{2}{|c|}{ Textural class } & Silty clay loam & Silty clay loam \\
\hline & \multicolumn{2}{|c|}{ Soil pH (1:2 Soil) } & 7.4 & 7.6 \\
\hline & \multicolumn{2}{|c|}{ Soil EC $\left(\mathrm{dSm}^{-1}\right)$} & 0.69 & 1.01 \\
\hline & \multicolumn{2}{|c|}{ Organic (\%) } & 0.67 & 0.49 \\
\hline & \multicolumn{2}{|c|}{ Total N (\%) } & 0.033 & 0.024 \\
\hline & \multicolumn{2}{|c|}{ Available P (ppm) } & 3.5 & 2.2 \\
\hline & \multicolumn{2}{|c|}{ Available $\mathrm{K}(\mathrm{mg} / \mathrm{g})$} & 201 & 190 \\
\hline
\end{tabular}
before sowing for both years 2015-16 and 2016-17.

\section{Weather conditions}

The average monthly meteorological data during cropping seasons of both years at the site of Tandojam, District Hyderabad, Sindh, Pakistan is presented (Figure 1).

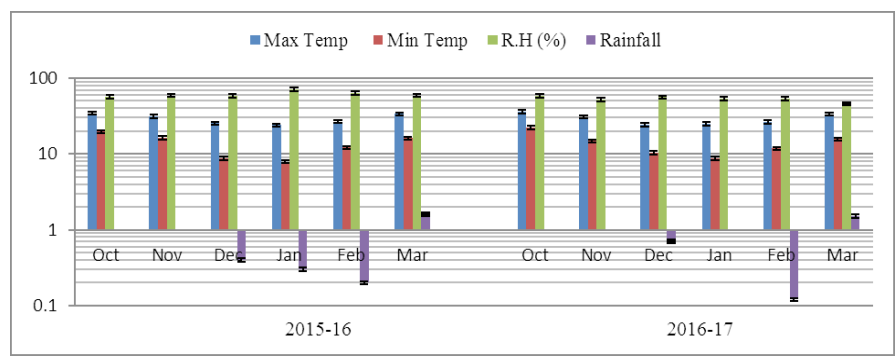

Figure 1: Monthly average mean of metrological data during crop growth and development of wheat crop.

Source: Regional Agrometrological Centre Tandojam, Sindh, Pakistan.

\section{Results and Discussion}

Seed Emergence $\left(m^{-2}\right)$

Seed emergence determines the initial growth stage of every crop. The data regarding seed emergence was 
significantly $(\mathrm{P}<0.05)$ influenced by cultivars in both years (Figure 2A). The cultivar, Moomal-2002 showed a significantly $(\mathrm{P}<0.05)$ higher number of seed emergence (222.2 and $223 \mathrm{~m}^{-2}$ ) as compared to other varieties. The greatest reduction in seed emergence (155.5 and $171.4 \mathrm{~m}^{-2}$ ) was found in cultivar Imdad-2005 in the year 2015-16 and 2016-17, respectively. The possible reasons for this variation in both years might be because changes in environmental conditions in the cropping area which may have a modifying effect on seed emergence. Our finding endorses the previous study of Zhang (2007) who reported that the significant variation in seed emergence of genotypes due to the effects of many biotic and abiotic factors. Moreover, Sorour et al. (1995) also observed that slightly differences in emergences due to the positive effects of varietal characters.

\section{Tillers plant ${ }^{-1}$}

The results exhibited that greatest tillers plant ${ }^{-1}(8.5$ and 10.1) were obtained in cultivar Moomal-2002 under both wheat growing seasons. The significantly $(\mathrm{P}<0.05)$ lowest tillers plant ${ }^{-1}(4.8$ and 5.5) were recorded in Imdad-2005 in both seasons (Figure 2B). Furthermore, the results showed that the tillers plant ${ }^{-1}$ were increased in the $2^{\text {nd }}$ season as compared $1^{\text {st }}$ season. It is well documented that the increasing of tillers plant $^{-1}$ also influence on the grain yield positively. The variability of tillers in cultivated cultivars in both years might be due to genetic variation in producing tillers, plant geometry, and changes in temperature in both seasons. These findings are supported by Ishag (1994) who concluded that hot weather conditions generally reduce tillers in wheat during the growth of crop plants. While similar results were also documented by Byerlee et al. (1984).

\section{Plant height $(\mathrm{cm})$}

Statistically analysis results of plant height were significantly $(\mathrm{P}<0.05)$ differences in both years (Figure 2C). Results of the present investigation indicated that the cultivar Moomal-2002 significantly $(\mathrm{P}<0.05)$ produced the tallest plants $(101.3$ and $100.8 \mathrm{~cm}$ ) under both seasons, respectively. While the shortest plant height $(63.2$ and $66.5 \mathrm{~cm})$ was noticed in cultivar Imdad-2005 during both seasons. The plant height is mostly associated with the genetic makeup of the parental material of each cultivar. Present results of our study are following Anderson and Olsen (1992) and Javadi et al. (2004) they suggested that the plant height enhanced significantly $(\mathrm{P}<0.05)$ to the timely planting and proper spacing and normal growing condition of an adapted wheat cultivar.

\section{Spike length (cm)}

The spike length $(\mathrm{cm})$ was significantly $(\mathrm{P}<0.05)$ influenced by cultivars under two growing seasons of wheat crop. The longer spikes (12.1 and 12.4 $\mathrm{cm})$ were produced by cultivar TD-1 under both growing seasons (Figure 3A). The significantly (P $>0.05)$ shorter spike length $(6.8$ and $5.6 \mathrm{~cm})$ was recorded in cultivar Imdad-2005 during both year 2015-17 respectively. The spike is the main yield component of wheat crop. The variation in spike length in all cultivars might have been associated with fluctuations in environmental conditions Under both seasons. Present results are agreed with Slafer and Whitechurch (2001) who suggested that the spike length may be increased and decrease due to genetical variation during the reproductive stage of wheat.

\section{Spikelets spike-1}

Our findings revealed that the wheat cultivars showed a significant $(\mathrm{P}<0.05)$ response for spikelets in both planting seasons. However, seasonal variation did not influence on spikelets spike ${ }^{-1}$ (Figure 3B). In the present study, the maximum number of spikelets spike $^{-1}$ (17.1 and 16.3) were observed in TD-1 in 2015-17, respectively. While significantly lower $(\mathrm{P}<$ $0.05)$ number of spikelets spike ${ }^{-1}$ (12.5 and 9.3) were produced by cultivar Imdad-2005 than the rest of the cultivar in both growing seasons. Spikelets spike ${ }^{-1}$ is one of the main yield contributing characters which greatly influences the grain yield. The variation in spikelets spike ${ }^{-1}$ in cultivars might be due to the genetic potential of the cultivar in producing spikelets spike ${ }^{-1}$.

These findings are in conformity with the previous study of Haider (2007) who observed that the higher spikelets spike ${ }^{-1}$ may be obtained through cultivable wheat varieties as compared to uncultivable varieties in normal season at adaptable growing conditions.

\section{Grains spike-1}

The data pertaining to number of grains spike ${ }^{-1}$ was significantly $(\mathrm{P}<0.05)$ differences as influenced by various genotypes under both seasons (Figure 3C). The present investigation was shown, significantly $(\mathrm{P}$ $>0.05)$ more grains spike ${ }^{-1}$ were obtained in 201516 as compared to the $2016-17$ year of cultivated cultivars. The cultivar TD-1 produced significantly $(\mathrm{P}<0.05)$ greater grains spike ${ }^{-1}(51.5$ and 47.9$)$ in 
both growing seasons than other cultivars. Moreover, higher degradation in grains spike ${ }^{-1}$ (39.2 and 36.1) was observed in cultivar Imdad-2005 under both seasons, respectively. The differences in grains spike ${ }^{-1}$ of cultivars might be due to increased and decrease constant temperature over during the reproductive growth and seed formation. Our finding is agreed with findings of Sial et al. (2001) and Bender et al. (1999) who suggested that the grains spike ${ }^{-1}$ was significantly influenced by various genotypes in different growing seasons. Moreover, previous research of Mehboob et al. (2005); Khan et al. (2007) who also observed that few cultivars have the potential to provide a greater number of grains spike ${ }^{-1}$ in different environmental conditions.

\section{0-grain weight $(g)$}

The present results showed that the 1000 -grains weight was slightly varied of various wheat cultivars in both study years program (Figure 4A). According to the present results, the highest 1000-grain weight (50.8 and $53.8 \mathrm{~g}$ ) was obtained from cultivar TD-1 followed by Moomal-2002 and Anmol-91, who produced (45.2 and $47.9 \mathrm{~g})$; (43.6 and $46.1 \mathrm{~g})$, respectively in two consecutive seasons. The significantly $(\mathrm{P}<0.05)$ greater reduction in 1000-grain weight was recorded in cultivar Imdad-2005 than other cultivars. The cultivar Imdad-2005 produced grain weight of (38.5 and $42.3 \mathrm{~g}$ ) under two growing seasons respectively. It was noticed that 1000 -grain weight was higher in the second year. This might be due to better vegetative growth of the wheat plants that leads to more production of tillers, resultantly more seeds with higher weight were produced. The same results have been documented by Sardana et al. (2002) and Singh et al. (2002) they suggested that the performance of various wheat genotypes was significantly $(\mathrm{P}<0.05)$ performed for 1000-grain weight $(\mathrm{g})$ under different growing seasons.

\section{Cultivars}
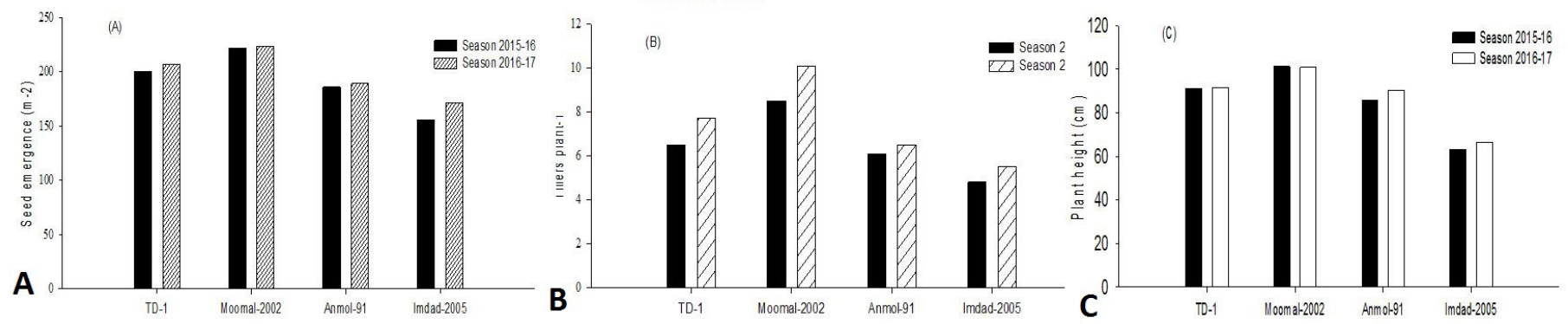

Figure 2: Seed emergence (m-2), tillers plant-1and plant beight $(\mathrm{cm})$ of wheat as affected by various cultivars under the agro-ecological conditions of Tandojam.
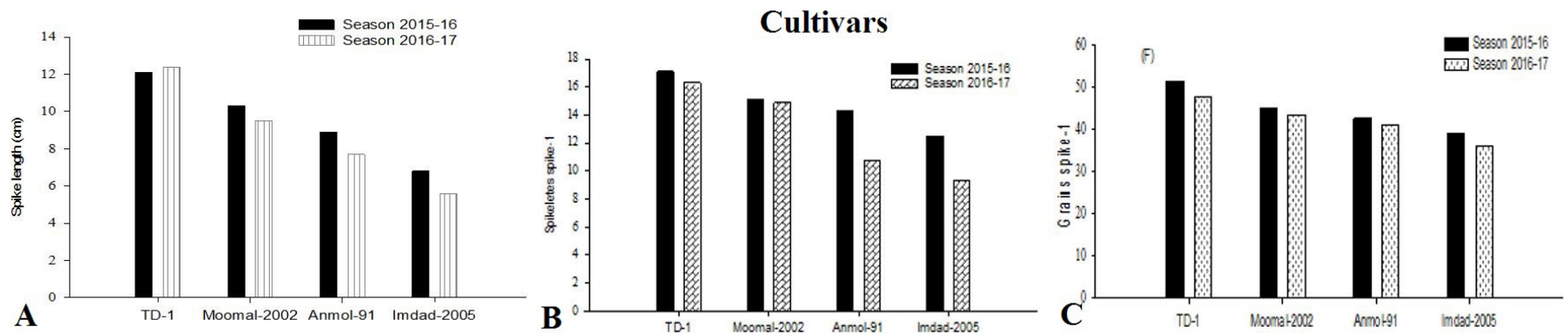

Figure 3: Seed emergence (m-2), tillers plant-1and spike length (cm), spikelets spike-1 and grains spike-1 of wheat as affected by various cultivars under the agro-ecological conditions of Tandojam.
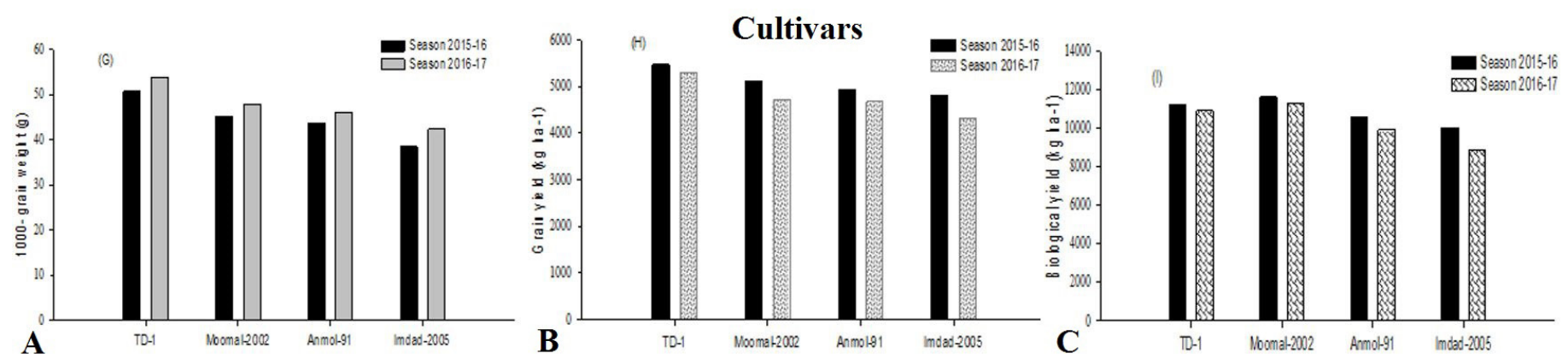

Figure 4: 1000-grain weight $(g)$, grain yield $(\mathrm{kg} h \mathrm{ha}-1)$ and biological yield $(\mathrm{kg} h \mathrm{~h}-1)$ of wheat as affected by various cultivars under the agro-ecological conditions of Tandojam.

March 2021 | Volume 34 | Issue 1 | Page 140 
Grain yield $\left(\mathrm{kg} \mathrm{ha}^{-1}\right)$

The crop yield is a final objective of any research program of every crop. In the present study, the different wheat cultivars were significantly $(\mathrm{P}<0.05)$ produced grain yield $\left(\mathrm{kg} \mathrm{ha}^{-1}\right)$ in both seasons (Figure 4B). The present investigation envisaged that among the cultivars, cultivar TD-1 consistently produced higher grain yield (5462.6 and $5300.5 \mathrm{~kg} \mathrm{ha}^{-1}$ ) as compared to Moomal-2002 and Anmol-91 showed (5100 and $\left.4720 \mathrm{~kg} \mathrm{ha}^{-1}\right) ;\left(4930.1\right.$ and $\left.4666.2 \mathrm{~kg} \mathrm{ha}^{-1}\right)$, respectively. The lower grain yield (4800.2 and 4320.6 $\mathrm{kg} \mathrm{ha}^{-1}$ ) was obtained from Imdad-2005 during the first and second growing seasons, respectively. Our findings endorsed that the results of Erkul et al. (2010) and Kusaksiz and Dere (2010), who documented that phenotypic plasticity has been noted in wheat cultivars under various growing seasons. Moreover, $\mathrm{Li}$ et al. (2013) also reported the same results regarding grain yield $\left(\mathrm{kg} \mathrm{ha}^{-1}\right)$ of wheat cultivars.

\section{Biological yield $\left(\mathrm{kg} \mathrm{ha}^{-1}\right)$}

Significantly $(\mathrm{P}<0.05)$ more production in the biological yield of cultivar Moomal-2002 which was observed in the year 2015-16 as compared to the year to 2016-17 than other cultivars (Figure 4C). The results of this study revealed that the greatest biological yield (11640.5 and $11300.3 \mathrm{~kg} \mathrm{ha}^{-1}$ ) was produced by cultivar Moomal-2002 during two consecutive years. This reflects that Moomal-2002 consistently showed higher seed emergence, tiller per plant, and plant height in both years. The lowest biological yield (10047.2 and $\left.8900.3 \mathrm{~kg} \mathrm{ha}^{-1}\right)$ was observed in Imdad-2005 under both growing seasons. In the present investigation, the biological yield differed significantly in both seasons. The highest biological yield was observed in the first growing season. This might be due to variation in environmental conditions in both growing seasons. Our findings are endorsed by many researchers including Jan et al. (2003); Arain (1999); Okuyama et al. (2005) who found that significant increase and reduction in biological yield among various cultivars might be due to late and early planting of wheat cultivars.

\section{Conclusions and Recommendations}

It is concluded that the wheat cultivar TD-1 and Moomal-2002 performed better for growth, development and yield-related characters as compared to other cultivars in both years. Therefore, wheat cultivars TD-1 and Moomal-2002 may be grown under the agro-ecological conditions of Tandojam, Sindh, Pakistan. However, further needs to be performed in different locations and environmental conditions to determine growth and yield-related traits of wheat crop.

\section{Acknowledgements}

Author is highly grateful and acknowledge the contributions of whole team of Agronomy Section ARI, Tandojam for support and kind guidance I am also thankful to Dr. Mahmooda Buriro for their valuable suggestions. I also express my sincere thanks to Dr. Niaz Ahmed Wahocho for their technical supports and guidance during the whole study program.

\section{Novelty Statement}

The experiment was laid out at Agronomy Section, A.R.I, Tandojam, wheat cultivar TD-1 and Moomal-2002 performed better for growth, development and yield-related characters as compared to other cultivars in both years. Therefore, wheat cultivars TD-1 and Moomal-2002 may be grown under the agro-ecological conditions of Tandojam, Sindh, Pakistan.

\section{Author's Contribution}

Tofique Ahmed Bhutto: Conducted field research and set the paper.

Dr. Mahmooda Buriro: Supervised the research study.

Zulfiqar Ali Abbasi and Nadar Hussain Khokhar: Provided technical inputs.

Dr. Niaz Ahmed Wahocho and Muhammad Iqbal Jakhro: Helped in revised manuscript and gave final shape for publication.

Safdar Ali Wahocho: Helped in seedbed preparation and cultural practices.

Fateh Muhammad, Reema Vistro, Fehmeeda Abbasi and Sanam Kumbhar: Helped in collected data from study area.

Conflict of interest

The authors have declared no conflict of interest.

\section{References}

Ali, M.A., M. Ali and Q.M. Din. 2014. Determi- 
nation of grain yield of different wheat varieties as influenced by planting dates in agroecological conditions of Vehari. Pak. J. Life Soc. Sci., 1: $5-8$

Ali, M.A., M. Ali, M. Sattar and L. Ali. 2010. Sowing date effect on yield of different wheat varieties. J. Agric. Res., 48: 157-162.

Anderson, A., and C.C. Olsen. 1992. Seed time, seed rate and nitrogen fertilization in different varieties of winter wheat. Tidsskr Planteavl., 96: 441-451.

Arain, M.A., M. Ahmad and M.A. Rajput. 1999. Evaluation of wheat genotypes under varying environments induced through changing sowing dates. Proc. Symp. New Genetical Approaches to Crop Improvement-III. Nuclear Institute of Agriculture, Tando Jam, Pakistan, pp. 163-173.

Aslani, F., and M.R. Mehrvar. 2012. Responses of wheat genotypes as affected by different sowing dates. Asian J. Agric. Sci., 4: 72-74.

Bender, J., U. Herstein. and C. Black. 1999. Growth and yield responses of spring wheat to increasing $\mathrm{CO} 2$, ozone and physiological stresses: A statistical analysis of 'ESPACE-wheat' results. Eur. J. Agron., 3: 185-195. https://doi. org/10.1016/S1161-0301(99)00009-X

Byerlee. D., A.D. Sheikh, M. Aslam and P.R. Hobbs. 1984. Wheat in rice-based farming system of the Punjab. Implications for research and extension. AERU/NARC/CIMMYT. Wheat Paper, 1984. pp. 49.

Elias, D., 2003. Wheat, world commodity at Glance. pp. 1-10.

Erkul, A., A. Unay and C. Konak. 2010. Inheritance of yield and yield components in a bread wheat (Triticum aestivum L.) Cross. Turk J. F Cr., 2: 137-14.

GOP, 2013. Agricultural statistics of Pakistan, bureau of statistics, finance division (Economic Wing), Government of Pakistan, Islamabad.

GOP, 2017-18. Economic survey of Pakistan, ministry of food, agriculture and livestock, Government of Pakistan, Statistics Division (Economic Wing), Islamabad.

Haider, S.A., 2007. Growth analysis in relation to sowing date in four varieties of wheat: A functional approach. J. Life Earth Sci. 2: 17-25. https://doi.org/10.3329/jles.v2i2.7492

Iqbal, M.S., A. Yar, A. Ali, M.R. Ansari,J. Iqbal and H.M. Akram. 2001. Effect of sowing date and seed rate on grain yield of wheat (cv.93-BT022) J. Agric. Res., 3-4: 217-220.

Ishag, H.M., 1994. Genotype differences in heat stressed wheat in the irrigated Gezira Scheme. In: Wheat in heat-stressed environments: Irrigated dry areas and wheat-rice farming systems.(Eds.):D.A. Saunders and G.H.Hottel. Proceedings of the International conference of wheat in hot, dry irrigated environments. Wad Medani; Sudan, 14 February 1993, pp. 170-174. Jan, I., M. Usman, I.H. Khalil and T. Jan. 2003. Performance of recently released wheat cultivars. Asian J. P1. Sci., 8: 627-632. https:// doi.org/10.3923/ajps.2003.627.632

Javadi, A., R. Rahimzada and A. Yavari. 2004. Comparison of traditional and mechanized planting methods at different levels and their impact on the performance of dryland seeding. J. Agric. Eng. Res. 5: 18-78.

Khan, M.I., M. Tila, F. Subhan, M. Amin and S.T. Shah. 2007. Agronomic evaluation of different bread wheat (Triticum aestivum L.) genotypes for terminal heat stress. Pak. J. Bot., 7: 24152425.

Kumar, S., Alam and N. Ali. 2003. Response of wheat (Triticum aestivum L.) varieties to sowing dates. J. Res. (BAU). 1: 56 -59.

Kusaksiz, T. and S. Dere. 2010. A study on the determination of genotypic variation for Seed yield and its utilization through selection in durum wheat (Triticum durum Desf.) mutant populations. Turk J. Fld Cr., 2: 188-192.

Li, Y.F., Y. Wu, N. Hernandez-Espinosa and R.J. Pena. 2013. Heat and drought stress on durum wheat responses of genotypes, yield and quality parameters. J. Cereal Sci., 5: 398-404. https:// doi.org/10.1016/j.jcs.2013.01.005

Mehboob, A.S., A. Arain, S. Khanzada, H. Mazhar, M. Naqvi, D. Umar and N.A. Nizamani. 2005. Yield and quality parameters of wheat genotypes as affected by sowing dates and high temperature stress. Pak. J. Bot., 3: 575-584.

Naeem, M., 2001. Growth, radiation use efficiency and yield of new wheat cultivars under variable nitrogen rates. MSc. thesis Dept. Agron. Univ. Agric. Faisalabad.

Okuyama, L.A., F.L. Carlos and B.N.J. Fernandes. 2005. Grain yield stability of wheat genotypes under irrigated and non-irrigated conditions. Braz. Arch. Biol. Technol., 5: 697-704. https:// doi.org/10.1590/S1516-89132005000600004 
Sardana, V., S.K. Sharma, A.S. Randhawa and V. Sardana. 2002. Performance of wheat (Triticum aestivum L.) varieties under different sowing dates and nitrogen levels in the sub-mountain region of Punjab. Indian J. Agron., 47: 372-377.

Shah, S.S.M. and M. Akmal. 2002. Effect of different sowing dates on yield and yield components of wheat varieties. Sarhad J. Agric., 2: $143-149$.

Sial, M.A., M.A. Arain, M.A. Javed and M.A. Rajput. 2001. Genotype environment interaction for grain yield in bread wheat. Proc. Pak. Acad. Plant. Sci., 1: 41-46.

Singh, C.B., J. Kumar, A.A. Khan, R.A. Katiyar and A.K. Katiyar. 2002. Effect of nitrogen and dates of sowing on yield and quality of wheat (Triticum aestivum L.) seeds. Prog. Agric., 2: 92-93.

Slafer, G.A., and E.M. Whitechurch. 2001.
Manipulating wheat development to improve adaptation. In: Application of Physiology in Wheat Breeding (Eds.): Reynolds, M.P., J.I. Ortiz-Monasterio and A. Mc. Nab. Mexico, D.F.: CIMMYT, pp. 160-170.

Sorour, F.A., M.A. Al-Sharkawy and M.S. Osman. 1995. Influence of tillage methods on the growth and yield of corn. Libyan J. Agric., 4: 47-50.

Tahir, M., A. Ali, M.A. Nadeem, A. Hussain and F. Khalid. 2009. Effect of different sowing dates on growth and yield of wheat (Triticum aestivum L.) varieties in district Jhang, Pakistan. Pak. J. Life Soc. Sci., 1: 66-69.

Zhang, L., 2007. Productivity and resource use in cotton and wheat relay intercropping. PhD thesis, Wageningen University, Wageningen, The Netherlands. pp. 188. 